\title{
Under One Roof
}

Living Together and Apart in an Urban-Supported Housing Scheme

\begin{abstract}
In this essay we share a musical performance ethnography, titled Under One Roof, as an example of one approach to critical arts-based research. The piece stems from commissioned research that took the form of an ethnography of an urban-supported housing scheme for people over 50 years of age. We discuss some tensions of conducting radical democratic performative work within a political climate characterized by the commodification of knowledge and marketization of science. This context provides a backdrop to subsequent reflections around performing praxis through a critical political and cultural engagement. Specifically, we consider how Under One Roof challenges dominant stories about homelessness, poverty, discrimination, alcohol and drug misuse, marginalization, and aging through privileging personal stories. We consider how students' participation through readings of the script during lectures made it possible, in Henry A. Giroux's terms, to "connect the practice of classroom teaching with important social problems." ${ }^{1}$ KEYWORDS Arts-based research; Critical pedagogy; Narrative; Performance ethnography; Songs
\end{abstract}

The politics of evidence-based research, ${ }^{2}$ the commodification of knowledge, ${ }^{3}$ and the marketization of science make commissioned research an increasingly complex and dangerous terrain. ${ }^{4}$ In our experience, those who commission research and evaluations often have fixed ideas about how they want the findings - the final report-to look, feel, and sound. It is not unusual for funding bodies to add a clause restricting what can be made public and/or who can access the findings. They might also have fixed ideas about how "data" are gathered and analyzed, leading to pressure to produce large volumes of data quickly, speedily analyzed, resulting in a tidy executive summary up front so that readers do not have to "wade through" a lengthy document. Within this culture, we have felt that some potential funders' requirements conspire to make it almost impossible to uncover pressing social issues such as oppression, marginalization, exclusion, and coercion.

Departures in Critical Qualitative Research, Vol. 9, Number 3, pp. 3-27. ISSN: 2333-9489, electronic ISSN: $2333-9497$ (C) 2020 by the Regents of the University of California. All rights reserved. Request permission to photocopy or reproduce article content at the University of California Press's Reprints and Permissions web page, https://online.ucpress.edu/journals/pages/reprintspermissions. DOI: https://doi.org/10.1525/dcqr.2020.9.3.3 
Since 2004, when we completed our doctoral studies, we have carried out research/evaluation projects as independent scholars and as members of university-funded research teams. In every project, we have been asked to produce a written report. Although the funders hold the purse strings and contractual power, and we are obliged to meet these requirements, we simultaneously recognize our ethical, democratic, and communitarian obligations: The participants are the ones we look to first to validate our findings, as they are the masters of our research in a way different from that of the funders. The participants hold the key to our ethical consciousness.

Under these circumstances we sometimes feel we are engaged in a type of guerrilla/subversive activity, walking a tightrope, with conflicting masters. We aim to fulfill each contract to the funder's satisfaction-for example, to produce a report that gives funders the evidence they require to facilitate change at the policy level. At the same time, we risk our work becoming "drive-through" research ${ }^{5}$ that has little concern for participants, their lives, voices, life conditions, and empowerment. Additionally, these research reports are seldom accessed by students, nor do they provide a particularly engaging resource if they do. Our fear is that, in this climate, the political and pedagogical potentialities of the project are not realized.

We resolve some of these tensions by recognizing there are multiple ways to communicate research, to reach multiple audiences, and to develop "a vision that is open to myriad ways of doing progressive, activist-based work." Morally, we see our funders as the ones who initiate the learning process by identifying a particular population at risk. But, having started the ball rolling, we are then charged as "radical agents of social change" to generate controversy, raise political awareness, ${ }^{8}$ and make our work relevant by pursing social justice agendas. ${ }^{9}$ These aims very much include creating resources that provoke critical pedagogy and are accessible to our community. Our aim, therefore, is to find, if necessary, subversive ways to work that recognize and have at their heart a communitarian, political, moral commitment. We see critical arts-based approaches as playing a pivotal role.

\section{A BRIEF BACKGROUND}

Under One Roof is a critical arts-based research project. It stems from a commissioned ethnography of an urban-supported housing scheme for people aged over 50 in the United Kingdom. ${ }^{10}$ The study was commissioned by two charities (the Addiction Recovery Agency and the St Monica Trust) whose 
concerns overlap in the areas of alcohol and drug misuse, aging, and housing provision. Both organizations have voiced concerns about the lack of affordable housing, the revolving door of homelessness, and those with dual diagnoses (such as mental illness combined with alcohol/drug addiction) who often fall through the cracks of healthcare/housing provision. While the roles and expectations of local authorities in the United Kingdom have been for in flux for some time, in the city this project took place they continue to provide some social housing, including a number of homes for people over 50. On this occasion, the council had identified two problem housing schemes catering to people over 50 that had attracted numerous antisocial orders. The council representatives on the steering group were skeptical that residents would take part in the research given their indifference to previous attempts to convene user forums and consultations. The backdrop to our researchalong with alcoholism, drug use, unemployment, marginalization, homelessness, antisocial behavior, poverty, aging, silence, the changing face of care, and increasing costs of social care-was a degree of apathy.

From the outset, we knew we were working with people who had been marginalized and dispossessed on several counts: Often they were of low socioeconomic status and had faced racial discrimination, homelessness, serious illness, and/or drug and alcohol issues. Their personal voice was often silent or absent from dominant discourse, replaced by stereotypical and sometimes stigmatizing portrayals. If these individuals are present at all in public discourse, they are often portrayed as "villains" and storied as "a drain on the system." How could we work in ways that respect the complexity of their lives? How could we challenge negative stereotypes that threaten their dignity? These individuals did not have opportunities to publicly challenge the damaging narratives awash in the media. Critical arts-based methodologies provide one possibility, offering a radically different way to do researchone that meets social justice agendas by creating resources that support critical pedagogy and democratic understanding. ${ }^{11}$

\section{METHODOLOGICAL CONSIDERATIONS}

As qualitative inquirers, we have come to recognize and take as our starting point that "not only does knowledge come in different forms, the forms of its creation differ." 12 If we are to more fully understand human experience and relational dynamics, there is a need to utilize multiple ways of knowing at every stage of the research process. This means, when we embed arts-based 
and performative methodologies in our research practice, it is more than a way of (re)presenting findings. For us, songwriting, performing, and other lyrical, rhythmic, and poetic processes make it possible to access and privilege "felt sense" (somatic, pre-linguistic, sensory experience) alongside or over logical, rational, and scientific ways of knowing. ${ }^{13}$ The latter with rigid, formulaic rules, ready categorization, and the illusion that if we follow these rules something of worth will be "found" in our "data"; the former always a humble, cautious "leap of faith" ${ }^{14}$ offering no such guarantees.

Over the past 15 years, as we have begun to tap into and explore the potential of arts-based methods in our research, we have learned, in an embodied way, that these make it possible to account for-or get closer to-what is missing if we rely exclusively on scientific methods. As Richard Siegesmund notes, much of what we experience in our lives and relationships cannot be put into words but is nonetheless "fecund with meaning." "Felt sense," he suggests, sits within a broader methodology of aesthetic inquiry, which is not reserved for the museum, conservatoire, or the chosen few, nor is it about beauty, connoisseurship, or sitting back and admiring but, rather, it provokes "engagement of living in the everyday." ${ }^{15}$ Under these conditions, writing a song (for example) provokes awareness, action, and understanding in the artist, both during the process of creation and then again each time a song is performed. This felt sense and awareness can then be passed on to others who read, hear, or interact with the song. It is this awareness that we believe is often missing in the social sciences.

Attempting to work through arts-based and performative methodologies inevitably invokes elements of our own biographies. ${ }^{16}$ In the case of Under One Roof, while in some ways we both differ from some participants/characters (e.g., ethnicity, age, socioeconomic status, educational privilege, health), our biographies intersect in other ways. Although these intersections were important during the fieldwork, they became particularly significant when creating the play. For instance, in the play Marcia is a Black, Afro-Caribbean woman in her 6os who sings the song "I'm Alright." On the surface, Kitrina's biography is markedly different, and yet Kitrina's reflexive diary reveals how their histories touch. This connection was important as Kitrina wrote "I'm Alright" to explore and express the complex tensions in Marcia's life.

Kitrina: My father came to Bristol as a child in the I930s as an immigrant with his parents from Ireland. Signs of Bristol's intolerance were written on boarding houses: "No dogs or Irish." Some 30 years later I was born on the edge of St. Paul's, in Kingswood, a suburb of Bristol and close to the "people's republic 
of Stokes Croft." This area is renowned across the UK as the starting place for 1980 s race and poverty riots. It's a place where a group of locals pinned down police in a battle outside the Black and White Café. Throughout my childhood I was taken by my mother to a church in Jamaica Street on the edge of St Paul's and Stokes Croft. I remember the congregation of this Pentecostal church as being multicultural, and what has stuck in my mind are the many Black women, their colourful clothes, and the physicality of their powerful, passionate singing.

A short while ago I remember sitting with a group of scholars talking about a project based on Bristol and we were, as a group, defining some of the city's characteristics. The things my educated colleagues identified were far from my reality. They identified the beautiful artistic buildings of the university, landmarks like the Wills Memorial Building, Cabot Tower, and the river. As a Bristolian, these things meant little to me. Traveling into the area where our research took place, I was nearer to where I was born. Observing this skylinethere is art but it's street art; there is a river but it's a river of diverse faces; there are buildings but they are functional, high-rise tenement flats and storage warehouses, some broken, some disused, and many boarded up. Clifton, home of the University of Bristol, is very different from Easton, St Paul's, Stokes Croft, and Lawrence Hill. While David and I both studied for our doctorates here, I "know" the city in a different way than David does. My family have stories about being rejected in similar ways to some of the people in this housing scheme.

Marcia said she didn't want to talk about racial tension. In her words, she didn't want to be "in that story." Was that because doing so would tell a story about racism as opposed to those aspects of life she valued-like learning to forgive? When David talked to her and her friend, they told him they were "alright." "Our way," they said, is to "forgive, 70 times 7 " - a biblical reference to when Jesus was asked how many times one should forgive a wrong. I know this story, I recognise this path, because it's my story too, the one I was given in that Pentecostal church decades ago. How can we expect to be forgiven when we bear a grudge or seek vengeance? I am with her, but I can see where forgiving has been problematic in the face of the dominant narrative of the time. She was, like many of the women of my childhood memories, telling us she trusted in God, and now she didn't want to rake up her past or be part of a racial story. What she did tell us, however, was a story of racism-she has been, and sometimes still is, verbally and physically abused by white people.

The song "I'm Alright" speaks to this dilemma. It is a multi-vocal, acapella harmony about disharmony and abuse and how some women choose to 
respond to it. The harmonies tell us much about the issue, as does the melody, which powerfully evokes some "thing" that cannot be communicated in words.

Through previous performance ethnographies, ${ }^{17}$ we have come to understand that performing is a way of knowing that "rests upon a faith in embodiment, in the power of giving voice and physicality to words, in the body as a site of knowledge.... It insists upon a working artist who engages in aesthetic performances as a methodological starting place." ${ }^{18}$

The majority of students we work with are not working artists, nor are they studying communication, music, drama, theatre, or performance. Nevertheless, recognizing the important contribution of arts-based methodologies, our responsibility is to create resources that help develop awareness of felt sense, emotional connection, embodiment, and what can be known through a performing body. While it is likely that many of our students enjoy music, those who will sing or play an instrument in public are rare. Given the importance of songs, not to include songs-written from the research we described above-would omit too much that is important. With this in mind, along with a script for Under One Roof, which includes the song lyrics, we provide links to the songs "Blue Funnel Line" (https://www. youtube.com/watch?v=cftAy_SaurY) and "These Things" (https://www. youtube.com/watch?v=ZHFfaIOpm9w), which are accessible on YouTube.

\section{UNDER ONE ROOF: THE SCRIPT}

\section{Cast}

Joni: housing support advisor, mid-6os, Bristolian; SHAUna: housing support advisor, piercings and tattoos, late 20s, Bristolian; Aston: resident, Black Jamaican, early 6os; GeOrGE: resident, white, a little frail, early 7Os; JUNE: resident, white, a little frail, about 70 ; Marcia: resident, Black Jamaican, early 6os; Paul: resident, white Scouser, mid-6os; TAG: resident, white, age unknown.

\section{Band}

Drums: Shauna; Bass: Aston; Lead guitar: Tag; Keyboards: Marcia

\section{Scene One}

Staged at a housing scheme for the over-50s, JoNI enters a room to the side of the housing scheme main entrance. She picks up an envelope and opens it. As she reads, she sits down. Her silence is interrupted by SHAUNA who enters, holding up a letter. 
Shauna: Is this true? Have you ... ? Can they do this?

JONI: Morning luv (stands and hugs)

SHAUna: (reads from letter) What's this about a "new role which reflects the changing landscape of housing stock"? This isn't housing stock-it's someone's home! And "the current needs of our clients... to create more professional service provision for tenants"? How is working nights at different housing schemes and spending less time with people gonna do that?

Joni: I'm too tired to fight, Shauna. I've done this too long. They're not letting us care anymore. They've tied our hands and I've been...

Shauna: (cuts in, not listening) This isn't housing stock! It's George's home! He's not a client-he's a person with his own life and hopes. Aston isn't a client-he's a person! How am I supposed to learn this role when they keep changing it? Learn what you've been teaching me? You said it's about trust! Where's the trust? How can they tell me this in a letter? You're my line manager! How come you didn't tell me?

JonI: I didn't tell you because I've just got a letter meself. Only mine tells me this is the end of the road for me, luv. I can't be retrained-I'm 64 . I can't suddenly be mobile, or work nights, Shauna. I'm not going to be here. I have no role.

Shauna: What d'you mean you have no role? Don't be absurd! What do they think about this? Do the residents know? What do the residents think? Haven't they talked to the residents?

Joni: Well, they've had consultations...

SHAUnA: Consultations? What is a consultation?

SHAUNA walks to drum kit and begins playing a rock beat. PAUL swaggers on stage left with a can of beer.

PAUL: Now those buying drugs ain't too fussy where they get the money. They'd rather mug someone who can't fight back. But me? I don't mind-come and have a go if ya think ya's hard enough! I'm still capable of fighting back. I'm street, I'm urban, I got tattoos, I can spit. They seem to spend a lot of time clutching their testiclesstrange sort of habit. I don't know if ya's noticed it? But I do worry about the old ladies. I'd like to think someone was looking in on them. Me? I'm quite happy here. Just don't need them trying to organise things for ya. No one bleedin' goes to 'em! Don't need this shoved down their neck thing: "We got some money so we have to make you go to 
a dance!" Form-a-dance club, do-something-else club, whatever-the-hell club, do-a-jigsaw bleedin' club!

PAUL fumbles with his front door keys in the lock. MARCIA enters slowly stage right, looking around.

Marcia: When I came here first, this was a lovely, lovely place. But as people change, going and coming, the place changed. But it doesn't bother me. I'm alright. If you don't forgive, God can't forgive you. He said forgive 70 times 7 . If we don't forgive, we're always in a story, every minute in a story. And I don't like it. You've just got to put aside some things sometimes. If you don't do that, you'll never get true in life. So nobody don't do me anything. Even if they do me, it doesn't bother me. What I have to do, I get along with it. I don't see no problem here. When somebody goes round gossiping-I think that's when the problem comes-when you talk about the other ones. And I'm not in that.

MARCIA walks to her front door as GEORGE arrives stage left, pushing a wheelchair full of groceries.

GEORGE: The problem for Beth, see, is she's not able to get about so she's stuck in that flat all the time. Even for anybody able-bodied it's bloomin' boring, you know what I mean? There's nothing actually to do. I usually take Beth out round the town and that. For me it's actually something to do, see. It passes the time. Otherwise I'd be watching TV all day. You know yourself that'll drive ya crazy! But I can't be there 24 hours a day-it's impossible. You just can't do it 24 hours a day.

GEORGE walks to the door next to MARCIA's and they chat. JUNE enters stage right, looking nervous.

June: Trapped. I feel trapped. All my family, my friends, my doctors is over there. It's not very far, but it is with that subway, people getting arrested and searched for drugs. Once it starts to get dark you're trapped. And you get some funny people, sort of, like. You shut the door, but you can't shut out the noise. There's no privacy! Best keep myself to myself.

JUNE moves to her front door as ASTON enters stage right.

Aston: I would rather live in a house where I can put my dreams to reality. I'd have a sense of freedom that I don't have here. I go through a lot of tribulation here. Most of the people in this building, I don't mean anything by this but I'm telling you the truth, it's just like they are waiting to go to the cemetery, you know? 
There is a loud crash stage left. TAG bursts on stage, scowling, ranting, and dragging a blanket full of stuff. The other residents hurry into their flats. TAG crashes through his front door, slamming it behind him.

\section{Scene Two}

Darkness falls and the moon rises. ASTON sits on a step and rolls a cigarette.

Aston: I was born in Jamaica and came here at 13 years of age. Next month I will be 62 . Back then I was more into doing wrong than right. I enrolled for the Long Green Technical College, but I was bad, I had a gun. I don't know why, just being blasted rude. I wanted to sell it, but I didn't think that the guy who was gonna buy it was gonna rob to buy it. I ended up in prison for six years and I became a loner. After that, my life just bounced about from place to place, moving around. Then I got myself involved with weed, which was then, it was nothing, you know. But nobody wants to know you, you go for a job, they don't want to know.

When I was 26, I made my family. Came to Bristol to visit Ryan. Even when you're in jail you have to have a friend and when you come out you leave them there. Ryan was moved here so I came up here. Then, I went back to Jamaica but came back here 'cause I realised the problem was not Black and white, the problem wasn't a problem of a man's skin, but his own thoughts. I started to look into life. I said to a few friends, look, the economy, the recession-Jamaica's not saving anything and there's a lot of old cars parked up all over the place. So I started shipping second hand spare parts to Jamaica, about 30 year ago. But as I say, that business went down. But I kept going back to Jamaica. One of the times I stayed there five years-(laughing) planted bananas! But I missed my children-nothing can pay for that. I've seen people go sick about that. I almost went sick. For that I came back.

I really haven't been well the last seven years. Had a couple of operations. Before, I couldn't walk from here to St Paul without sitting down six times! (laughing) I would sit on columns, sit by the lights, sit on people's garden walls, and they'd get to know me. Sometimes I was scared someone would say, "There's someone casing my house!" (laughs heartily) After the operations I took my stick and walked two times over St Paul's without sitting down. These are the things I am happy about. I have my daughters, my friends, I know I don't have anything to worry about. So now-just doing something till I die? I don't want to sit down all my life, just, like, waiting. Like how 
I explained to you about most of my friends-they say "I'm just gonna have a little drink." 'Cause I used to drink heavy, if you put a bottle there, that bottle will be finished by tomorrow, and that's the heavy stuff, the white rum. But I thought to myself, "What's this for? It's not needed." And now I'm trying to give up the tobacco, but I can't give up everything one time, it's built in the system, like a drink of water.

So now, I keep myself quiet. There's no one I can go out there and talk to and that's just the way it is. I'm a man. I'm Black. And I'm a cowboy. (laughs) But I have tried to learn from others. If someone lends you a house, why just sit there? Take care of it, do something, put things together. You know if someone kicks you it's gonna hurt so why plan to kick someone? And if you are planning to kill a man today, how do you know he's not the man who will pick you up tomorrow? Why not let him get on with life?

That's my daughter in that photo up there, with her cap. And that's my grandson. He went for an interview to see if he can go for a cap like hers. So now I have my children, I have my grandchildren. And there's a lot of things being thrown away in the UK now that can be useful in Jamaica, so it's a matter of recycling, and doing something like I did 30 years ago. That's why I would rather live somewhere, like a house, where I can put my dreams to reality. I'd have a sense of freedom that I don't have here. I go through a lot of tribulation here. But I have learned that if you cannot learn to forget, learn to forgive, right? Because if I couldn't forgive I wouldn't be here talking to you now, alright, 'cause we're talking about things. So this is why I need my freedom-if I don't have that I can't do anything. Even my own Black friends on the road right now, sometimes I am sick of them 'cause if I don't take care, they take me straight back to prison. But if I do my own thing, I can come home and lie down on my settee, you know? So these are the things I need right now, and most of the people in this building, I don't mean anything by this, but I am telling you the truth, it's just like they are waiting to go to the cemetery, you know? I don't see life that way. I just keep on searching.

\section{Scene Three}

JONI and SHAUNA are back at the coffee table, stage left.

JONI: I started work in '78. Back then jobs were word of mouth. So because of my cousin, I got a job working in elderly mentally infirmed, or so we called it. We didn't think about careers-it was 
a job. But it shocked me-the way they locked 'em up in attics, cellars, and asylums-just people who needed help. Of course, there was no training-you were trained as you went along. Nowadays you're trained to get over shock!

Shauna: So when did you became a warden?

JONI: When I first come here. Then they did away with that and I was made "residential manager." And then, well, as you know, they downgraded this place. It's not sheltered housing anymore it's "elderly preferred." Going back, I knew all my residents, you know everybody. And they looked to you, well some of 'em, and you were there to help.

Shauna: Now they never know when to expect us-or who to talk to.

Joni: Some of our residents have been here longer than me! Can you imagine how difficult it is for them with all the changes? The loss of contact, a friendly face?

Shauna: But isn't the whole point of our job to have daily contact?

Joni: Well of course it is! It seems so obvious. Then if a tenant needed help, we'd speak to them. If you got no response, or no positive response, you'd pass it on to the relevant agencies.

Shauna: I remember that first time you took me round...

Joni: Ah yeah, I showed you the door-knocker handles no doubt!

SHAunA: Yeah, I couldn't believe there were all these secret messages, that if...

Joni: Oh yeah. Well, most of the residents still don't lock their doors. They like us to come in. Like Harry, in number 6, still I'll knock his door and then if there's no sound or no message, I'll pop my head round the door. He needs a little bit more help and time, compared with some of the others. And, well, when you do door knocking daily they know we're coming, they expect you. So if they know we're coming in and they have to go out, they leave a sign-the door-knocker handle. They put it up to show us they know we are coming but they are out, so we don't worry.

Shauna: But what was so lovely Joni, was how, if the door-knocker was up and, say, George was out, you would put it down.

Joni: Well of course. Then when George came back, he knows we'd called. That's just as important. It's a little thing, but these things, these little things, is how we connect to people, it's how we build trust. 
Shauna: I remember you taking me in to see Harry as well, and before we went in you said, you should never go in and say, "Ohm you've got a problem dressing." You should say perhaps, "Do you want me to pass you your socks?" or "I know your legs are aching today, do you want me to put your sock over your feet?" You showed me a different way to be with people.

Joni: Respect. That's what it is. You were there only to help-you weren't there to perform the job of carer. But they've taken that away. We don't do any form of care.

Shauna: And do you remember shouting out before you go in, you would shout out, you know, little knock and then, "Mary! It's Joni."

Joni: Or others you'd shout out and stay put! It's all personal preference. You learn there's all sorts of ways of helping. When I first joined, if there was no family, you could go and get a prescription, or if they were out of milk you could pick up some milk. We weren't supposed to do the shopping, but we could pick up enough to keep them going. Most of them have no help from their family. Some have lost marriages, children, siblings. So if they want to talk, you let them talk.

SHAuna: So what's this about a consultation?

JONI: Ah, well, the council come in-or send a notice round and then they have a meeting. But nobody feels they're not listened to. So what's the point in showing up?

\section{Scene Four}

GEORGE meanders slowly through the corridors, fiddling with random objects as he goes.

GEORGE: We had a meeting last time, with the council, and they said they were allocating money to wheelchairs and automatic doors! But that was three years ago. We haven't heard anything since. That's the main thing.

You know, it's not even clear what the purpose of the building's for! Some of us get letters through the post that now it's a retirement home-but we don't know. That's the main thing.

And the alarms system go off of at nighttime-you just get off to sleep and it goes off and it goes often. And the door buzzer! (loud buzzer sounds, George chuckles) I moved over from by the motorway-I said, "Could you get us a quieter place?" Coz that was right by the road. And they said: "Oh yeah." But it's just as noisy you know? Ask the others, they'll say it's noisy. That's the main thing. 
I was on the streets from ' 92 , living rough, homeless, just fell into that, ended up down here. It's a bit difficult adjusting, moving in with mixed people. It's more difficult when you get older. I used to be able to take it with a pinch of salt-it don't bother me. So that's the main thing.

I've got a few quibbles about the place-like I can't open my windows. But I'm quite happy with the way things are. I'd just like a bit more leeway-why can't I open my windows? I'd like control over my own environment, my own little flat, so I can open the window if it gets too hot. But other than that, I'm quite happy here. I love this little flat.

\section{Scene Five}

The band members take their places and begin playing. PAUL walks to center stage and sings "Blue Funnel Line" ( D. Carless 20 IO, used with permission).

On the Blue Funnel Line I set to sea

On the Blue Funnel Line I left behind the grey Mersey

Like my father before and his father before, we fled poverty

As I waved from the deck and watched my mother wave back

One more man slipped from her grip

Oh she tried to hold on, yes she tried to hold on, I was too strong

On the Blue Funnel Line I followed my will and was gone

First stop into Glasgow, take whisky on board

It wasn't for sailors, but troops based abroad

Through the Suez Canal to bunker in Adan then sail on

Columbo, Malaya, round Hong Kong

Beer, women, good times rolled on

Three-month round-trips and six years since I'd left Mam

On the Blue Funnel Line, I'd followed my will now she is gone

Dunno why I done it, could've been a look in her eye

But I married that girl and moved off the Blue Line

Two kids pretty quick but a sandblasting job's a bitch

By then we had lost it, whatever we'd had

So I do what I do whenever life gets sad

I never saw 'em again, not her and not the kids

Back on the Blue Funnel Line I followed my will...

I kinda fell into Bristol, no work in the north

Squatted with Paddies, drank wine in the park

Had battles on Goose Green, built bonfires after dark 
Ten years on, I just got tired of that

Quit drinking, cleaned up, moved to this flat

Where I sleep with a light on and dream of a time still to come

When I'll join the Blue Funnel Line, follow my will and be gone

I'll ride the Blue Funnel Line, follow my will and be gone

I'll take the Blue Funnel Line and I shall follow my will

\section{Scene Six}

JONI and SHAUNA move through the corridor, talking.

Shauna: I've worked for local authority for just over 3 years now, but since I started I never believed a job could change so quickly. When I started off I was responsible for just one site. I was a static scheme manager, a ten-story block, 62 flats and basically everybody, except for those who didn't want the service, was visited every day, just have a little chat, ask how they are. Basically it's half carer, half good neighbor, friend.

JoNi: Seeing people that often, you do notice little changes.

SHAuna: Nowadays, I have to be mindful of the time. We're logged in and logged out. I'm always watching the clock. At the first site I visit of a morning I'm thinking I have to leave time in case I come across a problem at the next site. So you're always thinking of that. I don't even know how many people live here now.

Joni: There's three couples, nine single women, eight single men, but of course several of the singles have in fact got partners which they don't admit to, don't want to lose their tenancy. One bloke in his seventies has a partner who's in her forties and their nine-year-old has never lived anywhere else. Anyway, it's important to know about people and their backgrounds-you don't force it, but you need to know what you may be dealing with. The time of year I dread most is October-November. That's when the heating allowance is paid. Most of that goes on internal heating! Then they have no electric from November onwards. But we've no right to tell people how to spend their money. But I do get annoyed, if I'm honest, angry even. It's given for fuel!

Shauna: But if that's how people want to live their life, we can't force an issue when we're working 90-Ioo hours. You always seem to manage the difficult stuff, Joni.

Joni: Well, I've got past experience. Not myself, but my daughter has used drugs, and drink. So maybe I'm not as shocked as some of you lot. See, 
when you've dealt with things in your own personal life then you've got better insight into it haven't you?

Shauna: But how do you actually know they're...

JonI: Well I do. You know. It's behaviour, or something, or mood swings. Some people open up. One gentleman here said, "Yeah, I'm a user."

Shauna: Funny thing is, I can chat to those people maybe better than I can on the posh sites. I guess working with older people who only tell me about their bowels everyday just bores me! I'm just interested to know why're they doing it?

Joni: There's a reason, you know, there's always a reason. And I'd like to think that I can look at the bigger picture really. I try to chat to people. I never judge anyone 'cause like I say I got it in my own life. I think my daughter has been a great help to me, having to deal with her, and she has been challenging.

SHAuna: It was a shock, when I came here, to see people have a liquid breakfast. Some of them would say it's the hair of the dog, to make up for the night before.

JonI: We are "well watered!" There's is pubs within half a mile of this place. A lot of the drinkers here are loners-for a variety of reasons. They'll have a few drinks in the pub but the really hard drinking they do alone. So you can imagine, some of 'em get quite oiled, then come back to their hard drinks here. And that was the problem when I was warden -if they have a fall, or have problems getting in at 2 a.m., I'd have to deal with them.

Shauna: Some of the residents say: "This place never sleeps!"

SHAUNA moves stage left, facing out. TAG appears stage right, carrying a large pirate-knife. He faces away from SHAUNA.

JoNI: It's true, there's always someone coming in and out. Making a noise, causing a disturbance, but what do you do? We've got one guy who's been tagged...

TAG: Fruit flies, acrid stench

No fucker gonna fuck with me

I'm not a junkie, you're barking up the wrong tree

Shauna: ... should be gagged

TAG: But at the end of the day

Aren't we all a little fucked? 
SHauna: I try to steer clear of him, his language-every other word!

TAG: And I've tasted death, the coffin and the tears, black clothes and a wake

But I sang with the dead and got drunk

I don't know how many times, but when you've been hit You either know what it's for or you don't

You know how hard you were hit

And that's the thing, there's so many sides

What goes around comes around, know what I mean?

The wanting, the needing, the crave in your soul

It travels in your carcass, you push it to the edge

You push, further than the SAS

It's taken Io years to get this fuckin' place and

Shauna: and yes I know they need to live somewhere and we all use bad language on occasion

TAG: no matter what I said about the rules, the building it's an indoor prison only I've got the keys not you, you screws!

Shauna: Some do it 'cause they've never read a dictionary,

TAG: You comin' in here like a vicar, having an interview

Well I'm doing life here

Shauna: Some to shock-or for attention

TAG: I don't want to be in here

I'm the ASBO fucker, I've been tagged

6 p.m. to 6 a.m.- -and I can't handle it

Shauna: But maybe it's also "help me!"

TAG: I don't want to live with these beep, beep systems

And you know what?

From the little fuckin' squirrel

comes the old fuckin' acorn

and this is the nut

I'm my granddad's age-that's why I got this place:

'Cause I'm old

And they're getting on my nerves

she's getting on my nerves

SHauna: Even though they will fight you every inch of the way

TAG: so I go and rattle her cage 
SHAUNA: and knock your head off, you know?

TAG: and I'm wild, and they come

and they knock down the door

Shauna: There is a cry for help there.

TAG: But I know the system, I been out in the cold

So I thought, fuck it!

Become a little hamster

Live in a cage.

Scene Seven

JUNE stands center stage with a basket of laundry with sounds of a washer and drier in the background.

June: Two tubs and a drier, it's a disgrace!

One slot in the week and there ain't enough space

All of my washing to be done in an hour

I'm just an old lady, ain't got no power

It's not your turn go read the list

Not the right day try the pub or get pissed

Coz the washers are full so is the drier

Go back to your room and sit by the fire

Then you write to the council or wait on the phone

Sit in your flat have a good moan

Them what wrote the rota ${ }^{19}$ forget some can't speak

As yet any English and there's one who's a freak

But we all do our washing down in that room

If something's not sorted we'll riot quite soon

Nah, that's not our way and I think they know

So nothing happens not even a show

So queue for the washer in an air of ill rest

And the man from the council thinks me a pest

But I'm all out of energy all out of steam

Is it too much to ask to get my clothes clean?

GEORGE joins JUNE with his basket of laundry. They talk together and move side-stage to offer vocal accompaniment to MARCIA. MARCIA takes position center-stage to sing "I'm Alright." 


\section{Chorus}

I'm alright (echo) We alright

I'm alright now $W e$ got no problems

No there ain't no problem to me

I'm alright (echo) We alright

I'm alright now Don't need your belp now

No there ain't no problem to me

White girl say: Hey blackie!

Don't want your type living here

She kicked and she shoved

We looked for help from above

(Repeat chorus)

Pretend I don't hear

Don't want her living in my mind

Going down the road We know a better way

So we walk, We walk on in our way

(Repeat chorus)

\section{Scene Eight}

JONI and SHAUNA stand outside the building sharing a cigarette.

Shauna: So, what can we do? Can't we do something?

JonI: What do you want from me, Shauna? I've taught you as best I can.

Now this is your profession. Who am I? I'm about to be out of a job.

I don't even have a house myself! Where am I going to live?

Shauna: I don't believe that no one will listen, Joni. Somebody must care! I care! I've got to keep on trying-for them.

Whole cast onstage. Band begins playing "These Things" ( D. Carless 2010, used with permission).

June (sings): A train ride out of the dark into the light

'Cause my guy was no good

A punch, a kick, a say goodbye then ten long years had passed me by Now it's my time for good

Alone there on the intercity, you sat and listened to me

It's these things... 
Aston (sings): Some weed, some bud, a drink, a drop brought a little colour into my lot

It was high times and warm nights

Until a doctor said it's time to stop, put the bottle down before you drop

It was my time for a change of mind

Now I need a sanctuary and an arm around me

It's these things...

CAst (sing): Oh, oh, oh, oh, oh

GEORGE (sings): A house, a job, two kids, a dog, a family man is what I was

It's these things that brought me back

From the precipice when illness hits, turning, spinning, blown to bits

Was it my time? Who knows?

Now I need a sense of safety and you to stand beside me

It's these things...

SHauna (talks over music): It's not our fault, it's cause of the so say management that changes have come in. The residents feel we haven't got the time for them now, it's like we're not paid to care anymore. Going back it was more caring, but not now. Now it's paperwork and I don't like it. All the girls feel the same-too much paperwork. And to me, it seems like now we're there for the building, not for the people. It's almost as if as long as the building gets checked, it's okay. You know, fire alarm, intercom system, blah, blah, blah. But me? I'd rather be there for the people. I care about people. Obviously there's nothing we can do about it, they've stressed it time and time again: it's not going back to that system.

CAst (sing): Oh, oh, oh, oh, oh

$\mathrm{Oh}$, oh, oh, oh, oh

\section{REFLECTIONS}

If young people are to develop a deep respect for others, a keen sense of social responsibility, as well as an informed notion of civic engagement, pedagogy must be viewed as the cultural, political, and moral force that provides the knowledge, values, and social relations to make such democratic practices possible. ${ }^{20}$

We share with Henry A. Giroux the conviction that academics have an obligation to activate in students passion, enthusiasm, critical political awareness, and democratic principles. We recognize our fundamental role in sustaining an education system that prioritizes a democratic, civic, critical 
awareness. But to what extent can critical arts-based methodologies achieve these aims? We would like to consider this question by reflecting on responses we have received to Under One Roof. To date, we have performed the piece publicly with actors, published two songs as short films on YouTube, ${ }^{21}$ and asked students to perform the script during lectures or seminars. Below, we draw on responses from students taking a public health degree course where we were invited to give a guest lecture to explore how the piece stimulated critical awareness through offering a dialogical and democratic portrayal.

Elliot W. Eisner suggested that performance art has the potential to engage all the senses, making it possible to "communicate the way something feels, that is, its emotional character... and showing it makes empathy possible." 22 This type of "felt" and embodied process was evident in the responses of students who, through performing a variety of roles, engaged with the lives of people they were otherwise unlikely to interact with, yet they were able to develop empathy and some sort of connection. For example:

It was good insight on how people think. It gives you a better idea of how people live and deal with things in life. It is a creative idea-I think it would engage more people with it, which would give them a better idea of life. How they can deal with it. Playing the roles, acting them, would make you feel like you are in their place and know how it feels.

It brought out the emotions of the story. How the people are all different, and so much more so than reading just facts or statistics. The changes that one place can go through and how it can affect all those people individually and with the same issues. Felt like I was part of it. Using how people usually speak, e.g., swearing, slang, makes it seem more real/related.

This personal level of engagement did not appear to indulge or romanticize life, but in the context of this project, seems to help bridge the gap that we as a culture create by either omitting or storying the Other in negative or demeaning ways. Given that our interest is to provoke among students greater political awareness and social responsibility, the script provided an opportunity for students to see life from different positions and to bring their own positionality "where one stands in relation to the other" into focus. ${ }^{23}$ For example:

It was a good and creative way to teach. Also provided more insights for us. Also provides us alternative perspectives of health and enables us to see 
a broad view of an issue. Also provided creative and practical methods for exploring an issue which made it fun to learn and consider different outlooks, viewpoints, and perspectives of this issue.

It was strange. I used to do a bit of acting so I kind of went back to that automatically and treated it like it was another script. It wasn't until we gave feedback I fully appreciated the message.

Perceptions on Black men dealing drugs. This is almost an everyday struggle for some Black Afro-Caribbeans.... Some of these men, most of the time, are perceived as dealing drugs even when it's not the case. There is a stigma associated with Black Afro-Caribbean men and drugs. For instance, weed is a drug thought to have come from a Black man's land. Hence, they are perceived as uneducated groups of men, which is not always the case.

When these types of comments, particularly as in the extract above from a Black student, are shared in a multicultural group scenario, there is an additional layer of depth, insight, and weight. We are not telling students what they should learn, or pre-identifying learning outcomes, nor are we suggesting recommendations for what should be done. Rather, the play provides an evocative aesthetic realization, a realization that is artfully put. In contrast to remembering facts, students are invited to bring to the table what each finds emotive, challenging, surprising, and so on.

As the above responses illustrate, the script is also democratic by being inclusive: It layers different voices alongside each other to form a dialogical representation. This layering of diverse positions-combined with a resistance to privileging any single position-seemed to encourage students to weigh alternative interpretations. Inviting percipients to reflect on their own experiences as they consider the characters' experiences brings a further dialogical quality to the performance. It implies different lessons are likely to be gleaned by different people; subtly different meanings were drawn from the performance depending on the percipient's position. Education of this kind is radical within the current milieu in part because it stimulates a different type of engagement. Under One Roof activated not just logical reasoning and cognitive thought, but also "the sensory, emotional and kinaesthetic realities of social and cultural phenomena." ${ }^{24}$

Although we put our faith in this kind of pedagogy, sharing our work through a performance to our own students or during guest lectures is something we have found to be demanding and risky. Asking students who 
are pursuing a degree in public health or science to take these risks and to perform in front of their peers involves additional considerations. Potentially those colleagues who extend invitations for us to present/perform in their institutions may also feel uncomfortable or anxious with what we are doing with their students. Discussing these issues with colleagues has helped us realize that we are invited to give guest lectures for exactly this reason. The following comment from the course leader illustrates this point:

They had not done anything like this before, which was why this sort of thing was so valuable. It challenged them and made them really consider people's lives. I think that some found it nerve-racking and it clearly put some of the students out of their comfort zone, which I thought was good.... Others completely embraced it and jumped right in. I think it gave them a really fresh approach to research [and] an opportunity to walk in someone else's shoes (so to speak). They said it was different and they really enjoyed it. They felt included in the lecture as well because it was collaborative in nature so the students felt completely engaged.... Of course, I love the script and this way of working is so powerful and tapping into people's hearts does make people care about an issue and hopefully those small steps towards change will eventually help in the future. We can't give up!

\section{CONCLUDING THOUGHTS}

The reports that fulfill contractual obligations to funding organizations are rarely democratic-they are typically power-based textual representations that meet specific political and cultural requirements. Arguably there is a place for this type of representation, not least to provide evidence that is seen as credible and convincing by those who hold political and economic power. These reports have the potential to shift policymakers toward instigating or resourcing positive social change. If that happens, these texts have done their work. However, we are skeptical of this process because, within the current political climate, the boundaries of what is taken as credible and convincing evidence seem to have become so narrow that critical, democratic, communitarian forms of research are often excluded. A recurring result, it seems, is that recommendations place the greatest demands for change on those with the least resources to implement them.

Under One Roof and its accompanying YouTube resources provide one example of a critical and democratic route to conducting and disseminating social research. At a time when "education" is being widely substituted by 
"training," ${ }^{25}$ the creation of diverse research-informed pedagogical tools to provoke critical thinking, interaction, reflection, and engagement with the issues facing some of the most disadvantaged in our communities seems sorely needed. This places a responsibility on those of us engaged in funded projects to make our work more accessible, engaging, and democratic. Critical artsbased approaches such as this are an effective place to start.

\section{ACKNOWLEDGEMENTS}

The study on which this performance and article draw was funded by the Addiction Recovery Agency and St Monica Trust. Thank you to all the residents who invited us into their homes and shared their stories. All song lyrics (C) D. Carless \& K. Douglas 2oro. Used with permission.

KitRina Douglas is Professor of Narrative and Performative Research at the University of West London. Kitrina is a video/ethnographer/director, storyteller, musician, and narrative scholar whose research spans the arts, humanities, and social sciences. She publishes research as films, documentaries, poems, songs, stories, and musical theatre, along with written publications in academic journals, news media, film, and multimedia in order to make it accessible to diverse audiences. Correspondence to: Kitrina Douglas, University of West London, St. Mary's Road, Ealing, London W5 5RF, UK. Email: kitrina.douglas@uwl.ac.uk.

David Carless is Visiting Research Professor at University of Edinburgh and Queen's University Belfast. David is a researcher-writer-musician working on interdisciplinary projects across social science, education, and health using narrative, songwriting, filmmaking, and live performance approaches. Correspondence to: David Carless, Queen's University Belfast, 69-7I University Street, Belfast BT7 IHL, UK. Email: d.carless@hotmail.com.

\section{NOTES}

I. Henry A. Giroux, "Public Intellectuals Against the Neoliberal University," in Qualitative Inquiry "Outside” the Academy, ed. Norman K. Denzin and Michael D. Giardina (Walnut Creek, CA: Left Coast Press, 2014), 46.

2. Michael L. Silk, Anthony Bush, and David L. Andrews, "Contingent Intellectual Amateurism, or, the Problem with Evidence-Based Research," Journal of Sport and Social Issues 34, no. I (2010): 105-28.

3. Giroux, "Public Intellectuals Against the Neoliberal University," 45.

4. Norman K. Denzin and Michael Giardina, eds., "Qualitative Inquiry 'Outside the Academy," in Qualitative Inquiry "Outside” the Academy (Walnut Creek, CA: Left Coast Press, 20I4), 9-3I.

5. Maggie Kovach, “Thinking through Theory: Contemporary Indigenous Situated Research and Policy," in Qualitative Inquiry "Outside" the Academy, ed. Norman K. Denzin and Michael D. Giardina (Walnut Creek, CA: Left Coast Press, 2014), 92-Io6.

6. Irene Bloom, "Introduction: Global Perspectives on Poverty and Social Justice," International Journal of Qualitative Studies in Education 22, no. 3 (2009): 253. 
7. Ken Plummer, Sociology: The Basics (London: Routledge, 2010), I89.

8. Edward W. Said, ed., "On Defiance and Taking Positions," in Reflections on Exile and Other Essays (Cambridge, MA: Harvard University Press, 200I).

9. Norman K. Denzin, "Writing as Transformation," in Qualitative Inquiry and Human Rights, ed. Norman K. Denzin and Michael D. Giardina (Walnut Creek, CA: Left Coast Press, 2010), 265-67.

IO. The ethnography was part of a five-month study of the experiences and needs of vulnerable older people living in local authority accommodation that included exploration of international, national, and local perspectives. It focuses on one housing scheme comprising 25 one-bedroom flats. In our role as observer-advocates, we made daily visits over a six-week period at varied times of day (between 9:00 a.m. and II:00 p.m.) on weekdays, weekends, and public holidays. We spent time in the communal lounge and kitchen, toured the buildings and grounds, and visited residents in their flats. We conducted interviews and focus groups with 23 residents (Io women and I3 men from 22 of the 25 flats) who identified as English, Fijian, Jamaican, Scottish, and Somali. One flat was confirmed unoccupied, and we were unable to meet the residents of the other 2 flats. The average age of participants was 63, with the eldest being 78 and the youngest 49. During focus groups we took a broad focus, asking: "What's it like living here?" In follow-up interviews, when a degree of trust had been established, we used a condensed life history approach, supporting participants to share an account of their life in their own words focusing on events and issues that were important to them. These interviews were conducted either in a communal area or in the resident's flat. One interview was conducted through a translator as the Somali couple did not speak English. We also interviewed 6 housing support advisors, 2 visiting nurses, and I carer. We conducted a final coffee morning and sandwich lunch during which we presented the key findings of the research back to participants to seek their response and feedback.

II. Norman K. Denzin, Performance Ethnography: Critical Pedagogy and the Politics of Culture (Thousand Oaks, CA: Sage, 2003).

I2. Elliot Eisner, "Art and Knowledge," in Handbook of the Arts in Qualitative Research, ed. J. Gary Knowles and Ardra Cole (Thousand Oaks, CA: Sage, 20o8), 5.

I3. David Carless and Kitrina Douglas, "Songwriting and the Creation of Knowledge," in Musical Autoethnography: Creative Explorations of the Self Through Music, ed. Brydie Bartleet and Carolyn Ellis (Bowen Hills, QLD: Australian Academic Press, 2009), 23-38; Kitrina Douglas, "Signals and Signs," Qualitative Inquiry I8, no. 6 (2012): 525-32; David Carless and Kitrina Douglas, "Performance Ethnography as an Approach to Health-Related Education," Educational Action Research I8, no. 3 (2010): 373-88; David Carless and Kitrina Douglas, "What's in a Song? How Songs Contribute to the Communication of Social Science Research," British Journal of Guidance \& Counselling 39, no. 5 (2011): 439-54; Kitrina Douglas, "Song Writing as Reflexive Practice: 'Breathing Too Loud' to 'Signals \& Signs," Qualitative Inquiry 22, no. Io (2016): 798-802; Kitrina Douglas and David Carless, "Nurturing a Performative Self," Forum Qualitative Sozialforschung/Forum: Qualitative Social Research 9, no. 2 (2008): Article 23, http://www.qualitative-research.net/fqs-texte/2-o8/o8-2-23-e.htm. 
I4. David Carless, "It's a Leap of Faith, Writing a Song," Departures in Critical Qualitative Research 6, no. 2 (2017): 99-Io6.

I5. Richard Siegesmund, "Dewey, A/r/tography, and the Ab-Use of Global Dialogue," in Global Dimensions of Qualitative Inquiry, ed. Norman K. Denzin and Michael Giardina (Walnut Creek, CA: Left Coast Press, 2013), I43.

I6. Douglas, "Signals and Signs."

I7. David Carless and Kitrina Douglas, "Blue Funnel Line," youtube.com, 9 June 2015, https://www.youtube.com/watch?v=cftAy_SaurY; Kitrina Douglas and David Carless, "Finding a Counter Story at an Inclusive, Adapted, Sport and Adventurous Training Course for Injured, Sick, and Wounded Soldiers: Drawn In-Drawn Out," Qualitative Inquiry 21, no. 5 (2015): 454-66; "These Things" youtube.com, 29 July 20I5, https://www.youtube.com/watch?v=ZHFfarOpm9w; Carless, "It's a Leap of Faith, Writing a Song."

I8. Ronald J. Pelias, "Performative Inquiry: Embodiment and Its Challenges," in Handbook of the Arts in Qualitative Research, ed. J. Gary Knowles and Ardra L. Cole (Thousand Oaks, CA: Sage, 2008), I86.

I9. "Rota" is an English phrase meaning timetable, calendar, or roster.

20. Giroux, "Public Intellectuals Against the Neoliberal University," 46.

2I. Carless and Douglas, "Blue Funnel Line"; Douglas and Carless, "These Things."

22. Elliot W. Eisner, "Concerns and Aspirations for Qualitative Research in the New Millennium," Qualitative Research I, no. 2 (2001): I36.

23. Sharan B. Merriam et al., "Power and Positionality: Negotiating Insider/Outsider Status within and across Cultures," International Journal of Lifelong Education 20, no. 5 (2OOI): 4II.

24. Carl Bagley, "The Ethnographer as Impresario-Joker in the (Re)presentation of Educational Research as Performance Art: Towards a Performance Ethic," Ethnography and Education 4, no. 3 (2009): 284.

25. Giroux, "Public Intellectuals Against the Neoliberal University." 